\title{
A Review of "How to Steal a Country: State Capture and Hopes for the Future in South Africa"
}

Nkosingiphile Mkhize

DOI: https://doi.org/10.22151/politikon.48.5

Nkosingiphile Mkhize, from Johannesburg (South Africa), holds two master's degrees; one in Political Science (research component and defence awarded a distinction) from the Masarykova Univerzita, Czech Republic. The second MA degree in Public Governance (cum laude) from the University of Johannesburg School of Public Management, Governance and Public Policy. He is currently a Ph.D. Candidate with the University of Johannesburg School of Public Management, Governance and Public Policy. His theses focus on integrity, ethics, corruption and anticorruption, and risk management in the South Africa public sector. The broad areas of his Ph.D. thesis focus form part of his key research interests. E-mail: nkosingiphile.e.m18@gmail.com.

\section{Keywords}

African National Congress; Corruption; Gupta; Jacob Zuma 


\section{From a democratic "miracle" to a stolen country}

How to steal a country: State capture and hopes for the future in South Africa is a political affairs non-fiction book published in 2018 by Robin Renwick. The author used his diplomatic experience and familiarity with South African politics and politicians even before democracy (from 1987 to 1991) to write this comprehensive publication on the state of corruption and state capture in democratic South Africa. The book is a dexterously and well-structured insight into the corruption within the ruling party, which has also sailed out to the country's governance. The publication contains 145 pages with cartoons by Jonathan Zapiro - a South African cartoonist who also has been taken to courtrooms for the nature of illustrations of the former president Zuma presented to various media platforms. Interestingly, the book cover page contains former and late President Mandela's picture as a symbol of hope and leadership towards defeating a "new" enemy, called "state capture" and its' key players.

Renwick refers to corruption as an endemic threat that has been a factor in every African National Congress (ANC) leadership since the rise of democracy. However, he highlights the Jacob Zuma-led administration as the most corrupt and pioneer to the concept of "state capture" in the context of South Africa. The book chapters revolve around events, statements, reports, and even individuals who were either key players of state actions or victims of serious actions by those spearheads of state capture. For instance, there is a reference to "Gordhan versus Zupta", "Guptaleaks" and "Government at war with itself" (Renwick 2018). This structure succinctly addresses the subject of state capture in South Africa over the past two decades under democratically elected president Zuma.

The publication begins with a well-written introduction, entitled "From Mandela to Mbeki", where Renwick highlights that the saintly Mandela had a wily side as well. Nevertheless, the author does not go into detail on this claim, referring the reader(s) to another publication instead (Carlin 2013), that he recommends being comprehensive in unpacking the rowdy side of the former and late president Mandela (Renwick 2018, 12). The rest of the chapters, from the Nelson Mandela-led administration to the rise of the Cyril Ramaphosa-led regime captures this publication to be a crime-like novel, one that is like "the Napoleon Crime" (Renwick 2018, 6). Napoleon Crime's notion is demonstrated through the looting and unjustified impunity that numerous senior members of the national executive have enjoyed in democratic South Africa.

As much as the publication spells out all the negative and nexus between Zuma, the Guptas, and state capture, conversely, there are a few positive pointers that Renwick considers. These include the win against former president Thabo Mbeki for the top seat in 
the Republic's presidency, a statement made by the former opposition leader, Ms. Hellen Zille, which referred to Zuma as "this charming man" (Renwick 2018, 26). However, this provided a very limited perspective as Renwick, to some extent, ignored the political power that Zuma enjoyed before (even when he was fired as Deputy President of the Republic because of allegations against him), and even during his tenure as president of the Republic. According to Gumede $(2008,265)$, Zuma is one of the most popular leaders with a huge number of supporters - with some being non-ANC members.

The support was built on a left-wing populist coalition within the ANC comprising of trade unionists, socialists, unemployed youth, veteran guerrilla fighters, women's lobbies, supporters of causes ranging from the death penalty to virginity testing, black business tycoons, and evangelicals. One of the most noticeable supporters included Julius Malema, who was the ANC Youth League, however, currently, he is the Economic Freedom Fighters (EFF) President, who publicly announced that he will "kill for Zuma" (Posel 2014, 41). This showed significant support for the former president and his leadership. Until now, there has been not a single statement of this nature made in defence and support of a president or even a presidential candidate in South African politics. Interestingly, some of these "Zuma loyalists", as Renwick (2018, 60) refers to them, were later (in early 2017) seen to be opponents of the Zuma-led administration. This was when former minister Gordhan publicly was announced his unhappiness with the leadership of President Zuma and his relations with the Gupta (Renwick 2018, 60).

Another significant contribution of the book is what the notion of state capture entails, as a relatively new phenomenon in South African politics and current affairs. The book aptly demonstrates the notion of state capture as being characterised by factions. Factions divide the ruling party instead of having members who seek to further advance the interests of those who voted for them. Furthermore, state capture is frequently accompanied by a programme or movement driven by denialism, arrogance, abuse of power, total disregard of national institutions and constitution, and the endless use of the country's public purse to defend and deter wrongdoing. Most importantly, Renwick's view on state capture is that the actions and activities of capture are deliberate and systematic in nature.

\section{Any hope for a U-turn to a better South Africa?}

The hope for the future in South Africa started in Nasrec, when Ramphosa, whom President Zuma did not trust as a leader who would politically protect him from being held accountable for the allegations on his role in the state capture of South Africa, won the ANC presidential elections which also makes him hold the position of President in the Republic 
of South Africa. Renwick's view and some political analysts and commentators that should Nkosazana Dlamini-Zuma, who is now a minister of Cooperative Governance and Traditional Affairs (Cogta), have won the elections in Nasrec. It would have resulted in former President Zuma not being held accountable. Again, the author portrays South Africa's hopes to be championed by Cyril Ramaphosa since he is one of the key players in the business sector.

Overall, the author's view on Guptas' relations to the former President Zuma offers a limited perspective on the notion of state capture in South Africa since Zuma mentioned during the Zondo State Capture commission that both former President Nelson Mandela and Thabo Mbeki enjoyed a relationship with the Guptas, yet there was no outcry (Khumalo 2019). Some political reports/statements, however, suggest that this notion is not novel since the presence and relations of the Gupta family to senior executive members of the ANC is known to have started as early as days of Nelson Mandela and Thabo Mbeki (Daniel 2019; Institute of Security Studies 2019). With regards to relations with former President Zuma, the Institute for Security Studies (2019, 3) reports that the Gupta relations began in 2002. Therefore, the publication could have highlighted the genesis of state capture and what it means in democratic South Africa. Nevertheless, Renwick argues that hope for South Africa is both in restoring democratic values post the Zuma-led administration, and in ensuring that the ANC regains its majority and voters' confidence especially after the continuous allegations and endemic of corruption and state capture by ANC executive members.

The publication provides a solid account of what has been perceived to be the dark side of South Africa's democracy and the actions of those elected to lead the nation. However, the narrative that Ramaphosa as President carries a great chance for South Africa because of his strong exposure and familiarity with the world and African business sector, is somewhat misleading. This is because recently the President of the Republic, Cyril Ramaphosa, just like his predecessor, has been faced with several questions as an ongoing review to his leadership and integrity to leading South Africa towards sustainable and good governance. Questions that remain include:

- Is Cyril Ramaphosa going to do the same as Zuma, allow the country to be captured, but this time not by the Guptas but by the elite or white monopoly capitalists?

- During Zuma's tenure and involvement in state capture, is Ramaphosa above suspicion from all state capture activities, or is he another accomplice that the public is yet to know of (especially since he was the deputy president of the ANC and the Republic)? 
The book could be used in studies of the quality or (in)effectiveness of democracy or political leadership in South Africa. A second edition could focus on tracing the notion of state capture even in forthcoming presidential tenures in democratic South Africa. This edition could bridge the gap between the current edition, titled "How to steal a country: State capture and hopes for the future in South Africa" and Van Vuuren's publication titled "Apartheid, Guns, and Money: A Tale of Profit".

\section{References}

Carlin, John. 2013. Knowing Mandela: A personal portrait. New York: Harper Perennial.

Daniel, Luke. 2019. "Zuma on Gupta connection throws Mbeki and Mandela under the bus." The South African News, March 6, 2021. https://www.thesouthafrican.com/news/jacob-zuma-state-capture-gupta-friendswith-mandela-and-mbek/.

Gumedze, William M. 2008. "South Africa: Jacob Zuma and the difficulties of consolidating South Africa's democracy." African Affairs 107(427): 261-271. https://doi.org/10.1093/afraf/adn018.

Khumalo, Juniour. 2019. "Zuma: Mandela, Mbeki also enjoyed a relationship with Guptas but there was no outcry." City Press, March 1, 2021. https://www.news24.com/citypress/news/zuma-mandela-mbeki-also-enjoyedrelationship-with-guptas-but-there-was-no-outcry-20190715.

Posel, Deborah. 2014. "Julius Malema and the post- apartheid public sphere." Acta Academica 46(1): 32-54.

Renwick, Robin. 2018. How to Steal a Country: State Capture and Hopes for the Future in South Africa. London, United Kingdom: Biteback Publishing.

Van Vuuren, Hennie. 2017. Apartheid, Guns, and Money: A Tale of Profit. London, United Kingdom: C. Hurst \& Co. 